\title{
КРИТЕРІЇ, ПОКАЗНИКИ ТА РІВНІ СФОРМОВАНОСТІ ГОТОВНОСТІ ВИХОВАТЕДІВ ЗДО ДО РОЗВИТКУ МУЗИЧНИХ ЗДІБНОСТЕЙ ДІТЕЙ 4-7 РОКІВ
}

Стаття присвячена актуальній проблемі підготовки вихователів ЗДО до розвитку музичних здібностей дітей 4-7 років. Системний підхід до проблеми дослідження вказуе на те, що критерії, показники, рівні готовності вихователів ЗДО до розвитку музичних здібностей дітей 4-7 років не можна розглядати як ізольовані, самодостатні елементи підготовки. Автором доведено, щео перехід із рівня на рівень сформованої готовності характеризуеться створенням нової системи відношень між елементами. Розроблено систему компонентних критерїв та їх якісних показників сформованості готовності вихователів ЗДО до розвитку музичних здібностей дітей 4-7 років відповідно до структури цъього феномена, які відображають авторські модельні уявлення про його зміст та характеристики.

На основі визначення суті поняття «готовність вихователів ЗДО до розвитку музичних здібностей дітей 4-7 років» схарактеризовано його компоненти. Ціннісно-мотиваційний компонент оцінюеться за допомогою мотивацийно-аксіологічного критерію, когнітивний операційно-змістового, діяльнісний - діяльнісно-рефлексійного. Визначені критерії характеризуються показниками: мотиваційно-аксіологічний - ціннісне ставлення до майбутньої педагогічної діяльності, інтерес до опанування форм, методів та прийомів розвитку музичних здібностей дітей 4-7 років; потреба у досягненні успіху в професійній діяльності; операційно-змістовий - системність, дієвість; діяльнісно-рефлексійний сформованість умінь та навичок розвивати музичні здібності дітей 4-7 років; самооцінка вихователя щодо сформованої готовності до даного виду діяльності.

Автором диференційовано рівні готовності вихователів ЗДО до розвитку музичних здібностей дітей 4-7 років на основі традиційної триступеневої градації (високий, середній, низький). На основі здійсненого аналізу розкрито суть змісту готовності вихователів ЗДО до розвитку музичних здібностей дітей 4-7 років, схарактеризовано компоненти готовності, обьрунтовано критерії, показники та рівні сформованості означуваної готовності.

Ключові слова: підготовка, готовність, вихователь, розвиток музичних здібностей, діти 4-7 років, критерій, показник, рівень сформованості.

Постановка проблеми. Найваждивішим напрямком модернізації сучасної освіти є підвищення іiі якості. У зв'язку з цим досить актуальною є проблема підвищення якості дошкільної освіти, оскільки вона визначає якість наступних рівнів. Освіта як ресурс науки, техніки та мистецтва зазнає сьогодні корінних змін, пов'язаних із формуванням особистості дюдини - як суб'єкта демократичних відносин, що виникають у процесі адаптації в постійно міндивих соціально-економічних умовах.

Діяльність сучасного вихователя має бути заснована на його активній, творчій позиції, здатності розробляти та реалізовувати нові ідеї та технології. Чинна освітня парадигма орієнтуе заклади дошкільної освіти на пошуки ефективних шляхів виховання всебічно розвинутої особистості. У зв'язку з цим особливої актуальності набуває проблема формування готовності вихователя до музичного розвитку дітей дошкільного віку.

3 усіх видів мистецтва саме музика найбільш безпосередньо впливає на сприйняття та емоційний світ людини, іiі настрій і переживання. Різноманітність

“(С) Мкртічян О.А.

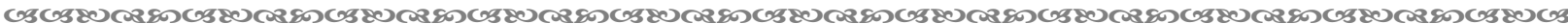
186 
душевних станів, їх сила і витончені нюанси, що розкривається в музиці, становлять іiі основний зміст.

Отже, у процесі професійної підготовки майбутніх вихователів особливої актуальності набуває проблема формування їхніх особистісних якостей та вмінь. Розв'язання даної проблеми дозводить здобувачам освіти бути готовими до здійснення розвитку дошкільнят засобами музичного мистецтва.

Аналіз досліджень. Вченими, які досліджували проблему підготовки вихователів до різних видів професійної діяльності, нині систематизовано комплекс критеріїв та показників для оцінювання даного виду роботи. С. Будак розробив комплекс критеріїв та показників для оцінювання готовності майбутніх вихователів ЗДО до навчання дітей іноземної мови. К. Волинець визначила показники, що розкривають загальнопедагогічну підготовку студентів цього фаху на засадах інтеграції. Н. Грама розробив комплекс критеріїв для оцінювання готовності здобувачів освіти до економічного виховання дошкільнят. Н. Емельянова сформулювала критерії визначення рівня підготовки студентів до опрацювання з дітьми народознавчої лексики. Власні комплекси критеріїв оцінювання готовності майбутніх вихователів до різних видів роботи запропонували такі вчені, як Н. Ковальова, О. Кучерявий, А. Машкіна, Т. Танько та інші.

Аналіз наукової літератури дає підстави стверджувати, що теоретико-методичні питання забезпечення підготовки вихователів до розвитку музичних здібностей дітей 4-7 років досі не отримали в ній достатнього відображення та потребують уточнення критеріїв, показників та рівнів сформованості готовності майбутніх фахівців до даного виду діяльності.

Мета статті - на основі аналізу наукової дітератури визначити критерії, показники та рівні сформованості готовності вихователів до розвитку музичних здібностей дітей 4-5 років.

Викдад основного матеріаду. У взаєминах із дитиною основною скдадовою професіоналізму вихователя $є$ його компетентність. Комунікативно компетентна людина встановлює певну атмосферу спілкування, що допомагає партнерові відчувати себе вільно та комфортно. Для розвитку дитини психологічний клімат відіграє особливу роль і визначається взаєминами з вихователем та іншими дітьми.

Результатом підготовки вихователів до розвитку музичних здібностей дітей 4-7 років є сформована готовність до даного виду діяльності.

Здійснений нами аналіз досліджень дозволяе констатувати, що підготовка вихователя ЗДО має бути комплексною. Готовність визначається як стан свідомості особистості, в контексті певних дій або підготовки до них, а також як спроможність майбутнього вихователя діяти на високому рівні, як одна $з$ умов швидкої адаптації до роботи та професійного вдосконалення. Готовність складається 3 теоретичних знань, умінь, позитивного ставлення до професії, фахової компетентності здобувача освіти.

Серед компонентів готовності визначимо: ціннісно-мотиваційний (ставлення до майбутньої професіі), когнітивний (сукупність знань із обраного фаху) і діяльнісний (набуті вміння та навички), які дозволяють вихователям продуктивно використовувати форми, методи, технології, засоби щодо вирішення професійних завдань, удосконалювати свою діяльність при їх застосуванні. Так, характерними особливостями діяльності вихователя щодо розвитку музичних здібностей дітей 4-7 років $є$ : координація дій і спрямованість суб'єктів освітнього процесу до вирішення питань музичного виховання дітей, урахування індивідуальних і вікових особливостей дошкільнят як основи розвитку музичних та творчих здібностей; організація та проведення масових заходів із вихованцями в рамках освітньої програми (музичні вечори, розваги, вистави дялькового театру); придбання музичних навичок і методичних знань; готовність до ділової співпраці як базисної педагогічної цінності, що дозводяе реалізувати наступність у роботі суб'єктів діяльності, забезпечення емоційно us 
позитивного фону в процесі професійної діяльності, що забезпечує позитивний вплив на його результативність; підвищення музичної грамотності вихователів, формування їх музичного смаку. Також, формування готовності щодо розвитку здібностей дітей проявляеться в музично-творчій активності вихователів (музична ерудиція, позитивне емоційно-оцінне ставлення до музичної культури, усвідомлення особливостей музичної мови, музичні враження, створення виразних музичних образів, керівництво музичнотворчою діяльністю дітей).

Розкриваючи суть кожного компонента готовності, визначимо його критерії та показники. Важливо наголосити, що рівень сформованості кожного із визначених нами компонентів готовності до розвитку музичних здібностей дітей 4-7 років оцінюеться за відповідними критеріями. Для вирішення завдань є необхідність чіткого виділення та формулювання критеріїв і показників готовності вихователів до розвитку музичних здібностей дошкільнят 4-7 років, що грунтуються на структурнофункціональних компонентах.

Зазначимо, що критеріадьний підхід до діагностування сформованості готовності майбутнього вихователя до розвитку музичних здібностей дошкільника розкривається через систему емпіричних показників, що уможливлюе виокремлення рівнів сформованості означеного процесу та його характерних ознак.

У педагогічній теорії «критерій» є об'єктивною ознакою, за допомогою якої здійснюеться порівняльна оцінка певного явища, сукупність якостей явища, які відображають суттєві характеристики й підлягають оцінці.

П. Ясінець зазначає, що критерій - це міра оцінювання досліджуваного явища і тих змін, що відбулися в результаті експериментального навчання та виділених педагогічних умов, за яких визначена гіпотеза відповідае чи не відповідає результатам експерименту [8]. Беручи за основу цю дефініцію, критерієм вважаємо ознаку, на підставі якої здійснюється оцінка, визначення або класифікація явища, процесу або діяльності.

На думку Г. Шабанова, ступінь вияву та якісна сформованість критерію виражаються показниками, які характеризуються низкою ознак, вкдючаючи певні складові, одиниці виміру, що дають змогу «виміряти» (оцінити) дійсність, порівняти іiі 3 нормою.

Таким чином, розгорнутий критерій $е$ сукупністю основних показників, які розкривають норму, вищий рівень розвитку досліджуваного педагогічного явища [7].

Розкриємо суть кожного компонента готовності. Доцільно зазначити, що зміст мотиваційного компонента готовності вихователя до розвитку музичних здібностей дошкільника акумудюе позитивно активне ставлення до фахової діяльності, мотивованість майбутнього фахівця до творчості, інтерес до музичної діяльності.

Критерієм сформованості мотиваційного компонента готовності вихователя до розвитку музичних здібностей дітей 4-7 років визначено мотиваційно-аксіологічний, а показники його вияву такі: цілеспрямованість студентів щодо фахової діяльності, досягнута шляхом формування готовності до розвитку музичних здібностей дітей 4-7 років, емоційна привабливість та позитивна мотивованість до музичної діяльності та формування ціннісних орієнтацій дошкільнят засобами музичного мистецтва (особистісні цінності).

Здібності особистості знаходять своє вираження в ціннісному ставленні до оточуючого, в якому діяльнісне, оцінне й емоційне упорядковуеться в досконалості, гармонії та красі. Ціннісне ставлення до музичного мистецтва грунтуеться на музичному сприйманні як основі музично-творчої діяльності. Залучення дюдини до світу музики супроводжується почуттям переживання, забезпечується виявлення особистісного смислу музичного твору, формуються також особистісні смисли та система цінностей індивіда. 
Слід зазначити, що формування готовності майбутнього вихователя до розвитку музичних здібностей дітей 4-7 років здійснюеться шляхом розкриття у процесі фахової підготовки мотивів, ціннісних орієнтацій, потреб, настанов студента як суб'єкта музичної діяльності.

Показниками рівня сформованості ціннісно-мотиваційного компоненту готовності вихователів ЗДО є:

- інтерес до освоєння методів розвитку музичних здібностей дошкільників;

- активність участі в музичній діяльності під час навчання у 3ВО;

- самостійність у виборі творчих завдань;

- прагнення брати участь в мистецьких конкурсах;

- активна, зацікавлена участь в обговореннях результатів реалізації мистецьких проектів і програм;

- наполегдивість у подоланні труднощів при вирішенні творчих завдань.

- активність у саморозвитку, прагнення дізнатися, вивчити більше, ніж пропонують навчальні програми.

Високий рівень сформованості ціннісно-мотиваційного компонента готовності вихователя 3ДО до розвитку здібностей дітей 4-7 років характеризується такими ознаками : він з інтересом ставиться до професії в цілому і до музичної діядьності зокрема, вважаючи це важливим для свого майбутнього; самостійно вирішуе творчі завдання, регулярно бере участь в розробці та реалізації мистецьких проєктів у складі групи або індивідуально; регулярно бере участь у музичних конкурсах; проявляє активність у саморозвитку.

При середньому рівні сформованості ціннісно-мотиваційного компоненту готовності вихователь ЗДО зацікавлено та відповідально ставиться до освоєння методів роботи 3 дітьми щодо розвитку їх здібностей, вважаючи, що це може стати в нагоді в майбутньому; нерегулярно, але бере участь у розробці та реалізації мистецьких проектів у складі групи або індивідуально; може самостійно ставити завдання, але не виявляє належної наполегливості при виникненні труднощів, може брати участь у мистецьких конкурсах, але не дуже до цього прагне; проявляе зацікавленість у саморозвитку, але з невисокою активністю.

Низький рівень сформованості ціннісно-мотиваційного компонента готовності характеризується тим, що вихователь: не проявляе інтересу до освоєння методів роботи 3 дошкільниками в галузі розвитку їх музичних здібностей, оскільки не вважає це важливим для свого майбутнього; не проявляе інтересу до участі в розробці та реалізації мистецьких проектів; не проявляе активності в професійному саморозвитку й не прагне дізнатися більше того, що пропонують навчальні програми, у нього домінуе звичка робити все заради позначки, що породжує пасивність щодо професійної підготовки.

Когнітивний компонент сформованості готовності вихователя 3ДО відображає його творчу освіченість, професійну компетентність, а також поінформованість про специфіку розвитку здібностей дітей 4-7 років і передбачає наявність у майбутнього вихователя певного рівня обізнаності з поняттями «здібності», «музичні здібності», «музична діяльність».

Когнітивний компонент сформованості готовності вихователів ЗДО до розвитку дитячих музичних здібностей передбачає сукупність знань і вмінь, отриманих у ході освітнього процесу, визначається операційно-змістовим критерієм і включає такі знання, як : методологічні, що передбачають знання сутності музичної діяльності та специфіки іiі реалізації в сучасних умовах; теоретичні, що включають знання цілей, змісту, методів і форм музичної роботи з дітьми 4-7 років, закономірностей ії освоєння, а також реалізації музичної діяльності; методичні, які об'єднують знання методики реалізації вимог особистісно-орієнтованого освітнього процесу в структурі власної 
діяльності; технологічні, засновані на основі сучасних педагогічних технологій розвитку музичних здібностей дітей 4-7 років.

Показники когнітивного компоненту: володіння аналітичними навичками; наявність загальних і спеціальних знань; володіння методами музично-педагогічних досліджень; здатність до організації самостійної пізнавальної діяльності.

Когнітивний компонент відображає наявність комплексу знань i вмінь, що сприяють осмисленню сутності та специфіки професійної діяльності вихователя. Це можливо при наявності аналітичних (теоретичний аналіз педагогічних факторів і явищ), прогностичних (орієнтування на кінцевий результат, визначення мети та змісту педагогічних завдань, відбір видів діяльності, адекватних поставленим завданням, планування творчих справ; вибір оптимального поєднання форм, методів і засобів педагогічного процесу; планування прийомів стимулювання активності учнів), проєктивних (конкретизація i обгрунтування способів поетапної реалізації педагогічного прогнозування), рефлексивних умінь (контрольно-оцінна діяльність).

Отже, постійне систематичне i послідовне прагнення задовольняти власні пізнавальні потреби, розвивати необхідні вміння аналізувати різні явища в галузі музично-педагогічної діяльності, опановувати системою розумових операцій, методів, прийомів, знання законів у поєднанні з умінням враховувати їх у музичній практичній діяльності сприяє вдосконаленню майбутнього вихователя в умовах ЗВО.

Критерієм сформованості когнітивного компонента готовності вихователя до розвитку музичних здібностей дітей 4-7 років визначено операційно-змістовий, а показниками його вияву такі:

- розуміння ролі та значення вирішення музично-педагогічних завдань у професійній діяльності вихователя;

- знання типів завдань, що вирішуються вихователем у професійній діяльності та вимог до результатів їх вирішення;

- знання вимог, що пред'являються до музичних проєктів і програм;

- знання методів вирішення музично-педагогічних завдань і умов їх застосування.

Високий рівень сформованості когнітивного компонента готовності вихователів ЗДО до розвитку здібностей дітей 4-7 років характеризується тим, що вихователь розуміє роль і значення вирішення музично-педагогічних завдань у професійній діяльності; має знання достатні, щоб вирішувати творчі завдання всіх типів.

При середньому рівні сформованості когнітивного компонента готовності до розвитку музичних здібностей дітей 4-7 років вихователь достатньо розуміє роль і значення вирішення музично-педагогічних завдань у професійній діяльності, має достатні знання, щоб вирішувати деякі найпростіші творчі завдання.

Низький рівень сформованості когнітивного компонента готовності вихователів ЗДО до розвитку здібностей дітей 4-7 років характеризується тим, що вихователь не розуміє роль і значення рішення музично-педагогічних завдань у професійній діяльності; має недостатні знання, щоб вирішувати будь-які завдання творчого характеру.

Отже, змістове наповнення когнітивного компонента надає мождивості оцінити його за допомогою операційно-змістового критерію.

Діяльнісний компонент готовності вихователів до розвитку музичних здібностей дітей 4-7 років формується через систему практичних дій, представлений групами умінь, систематизованих за провідною ознакою діяльності.

Критерієм оцінювання сформованості діяльнісного компонента готовності вихователя до розвитку музичних здібностей дітей 4-7 років визначаємо діяльніснорефлексійний, ознаками кого є: здатність застосовувати набуті знання, уміння та навички у своїй професійній діяльності. володіння досвідом та навичками розвитку музичних здібностей дошкільників, адекватною самооцінкою вихователя щодо сформованої готовності до даного виду діяльності.

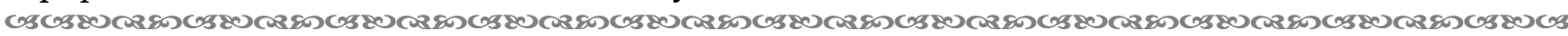
190 
Показниками діяльнісно-рефлексійного критерію є: сформованість умінь, навичок, здатність до здійснення музичного розвитку музичних здібностей дітей 4-7 років; сформованість умінь застосовувати знання в музичній діяльності; сформованість навичок розв'язання проблем, пов'язаних з професійною діяльністю в галузі музичної освіти; адекватна самооцінкою вихователя щодо сформованої готовності до даного виду діяльності.

Високий рівень сформованості діяльнісного компонента готовності вихователів ЗДО до розвитку здібностей дітей 4-7 років характеризуеться тим, що вихователь: здатний успішно здійснювати музичний розвиток дітей 4-7 років; вміє застосовувати знання в музичній діяльності; має сформовані практичні навички; здатний до розв'язання творчих завдань, пов'язаних із музичною діяльністю, має адекватну самооцінку щодо сформованої готовності до даного виду діядьності.

При середньому рівні сформованості діяльнісного компонента готовності вихователів 3ДО до розвитку здібностей дітей 4-7 років характеризуеться тим, що вихователь: здатний у достатній мірі здійснювати музичний розвиток дітей 4-7 років; ситуативно проявляе уміння застосовувати знання в музичній діяльності; має частково сформовані практичні навички в розв'язанні творчих завдань, пов'язаних із професійною діяльністю; має завищену самооцінку щодо сформованої готовності до даного виду діяльності.

Низький рівень сформованості діяльнісного компонента готовності вихователів ЗДО до розвитку здібностей дітей 4-7 років характеризуеться тим, що вихователь: не здатний здійснювати музичний розвиток дітей 4-7 років; має недостатньо сформовані практичні навички; не вододіє навичками розв'язання творчих завдань, пов'язаних із професійною діяльністю, має неадекватну самооцінку щодо сформованої готовності до даного виду діяльності .

Таким чином, здійснення розвитку музичних здібностей дітей 4-7 років постає важдивим чинником професійної діяльності вихователя ЗДО.

Висновки. Необхідність професійної підготовки вихователів ЗДО до розвитку музичної діяльності дітей 4-7 років обумовлена різноманіттям форм і видів педагогічної діяльності, специфікою роботи з дошкільниками. Музичне мистецтво допомагає вирішувати завдання духовного, морадьно-естетичного виховання дитини і відіграє особливу роль у іiі розвитку. Розвиток музичних здібностей дітей 4-7 років завжди належав до важдивих педагогічних завдань, адже саме дошкільний вік є сензитивним щодо розвитку всіх основних психічних процесів, здібностей, зокрема і музичних.

Формування готовності вихователів ЗДО до розвитку музичних здібностей дітей 4-7 років - складний і тривалий освітній процес, який оцінюється сформованістю відповідних компонентів: мотиваційного, когнітивного, діядьнісного. Відповідно кожен компонент оцінюється певними критеріями : мотиваційно-аксіологічним, операційнозмістовим, діяльнісно-рефлексійним. Ціннісно-мотиваційний компонент характеризується аксіологічним ставленням студента до майбутньої професійної діяльності; опануванням технологій музичної підготовки дітей дошкільного віку; когнітивний - передбачає сукупність професійних знань і умінь, отриманих у ході освітнього процесу, діяльнісний - становить систему практичних дій, представлену групами музичних умінь та самооцінкою щодо сформованої готовності до даного виду діяльності. Визначено рівні готовності вихователів до розвитку музичних здібностей дітей 4-7 років на основі традиційної триступеневої градації: високий, середній, низький. На основі здійсненого аналізу розкрито суть змісту готовності вихователів до розвитку музичних здібностей дітей 4-7 років, схарактеризовано компоненти готовності та обгрунтовано критерії, показники та рівні сформованості означуваної готовності.

Перспективи подальших досліджень полягають у теоретичному обгрунтуванні та експериментальній перевірці розробленої системи підготовки вихователів закладів дошкільної освіти до розвитку музичних здібностей дітей 4-7 років.

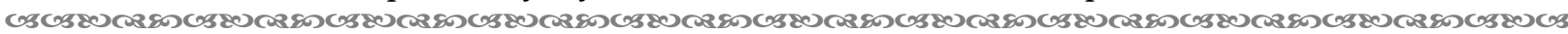
191 


\section{Список використаних джерел:}

1. Бєлєнька Г. В. Вихователь дітей дошкільного віку : становлення фахівця в умовах навчання. Київ : Світич, 2006. 304с.

2. Воронюк І. В. Психологічні особливості реалізації творчого потенціалу молодших школярів : дис. ... канд. психол. наук : 19.00.07. Нац пед. ун-т ім. М. П. Драгоманова. Київ, 2003. 20 с.

3. Дичківська І. М. Інноваційні педагогічні технології. Київ : ВІПО Л, 2004. 256 с.

4. Желанова В.В. Готовність майбутнього вихователя до розвитку творчого потенціалу дошкільника: сутність та структура. Науковий вісник Ужгородського національного університету: Серія: «Педагогіка. Соціальна робота». Ужгород : Ужгородський національний університет, 2016. Випуск 1 (38). С. 123-126.

5. Замелюк М. Діагностика готовності майбутніх вихователів до професійно-педагогічної діяльності з обдарованими дітьми. Освіта та розвиток обдарованої особистості. 2015. № 5 (36). С. $38-42$.

6. Кононко О. А. Орієнтир сьогодення - компетентна особистість. Дошкільне виховання. 2005. № 7. C. 7-9.

7. Шабанов Г. А. Развитие педагогического творчества преподавателей военноучебных заведений : дис. ... канд. пед. наук : 13.00.08. Москва. 25 с.

8. Ясінець П. С. Якість освіти у ВНЗ. Київ : Лібра, 2008. 212 с.

\section{References:}

1. Bielienka, H. V. (2006). Vykhovatel ditei doshkilnoho viku: stanovlennia fakhivtsia v umovakh navchannia [Educator of preschool children: becoming an educational specialist]. Kyiv: Svitich [in Ukrainian].

2. Voronyuk, I. V. (2003). Psykholohichni osoblyvosti realizatsiyi tvorchoho potentsialu molodshykh shkolyariv [Psychological features of realization of creative potential of junior schoolchildren]. (Extended abstract of candidate's thesis). National Pedagogical Dragomanov University. Kyiv [in Ukrainian].

3. Dychkivska, I. M. (2004). Innovatsiini pedahohichni tekhnolohii [Innovative pedagogical technologies]. Kyiv: VIPOL [in Ukrainian].

4. Zhelanova, V. V. (2016). Hotovnist maibutnoho vykhovatelia do rozvytku tvorchoho potentsialu doshkilnyka: sutnist ta struktura [Readiness of the future educator for the development of the creative potential of the preschooler: essence and structure]. Naukovyi visnyk Uzhhorodskoho natsionalnoho universytetu: Seriia: Pedahohika. Sotsialna robota, 1(38), 123-126 [in Ukrainian].

5. Zameliuk, M. (2015). Diahnostyka hotovnosti maibutnikh vykhovateliv do profesiinopedahohichnoi diialnosti z obdarovanymy ditmy [Diagnosis of future educators' readiness for professional pedagogical activity with gifted children]. Osvita ta rozvytok obdarovanoi osobystosti, 5 (36), 38-42 [in Ukrainian].

6. Kononko, O. L. (2005). Oriientyr sohodennia - kompetentna osobystist [Today's focus is a competent person]. Doshkilne vykhovannia, 7, 7-9 [in Ukrainian].

7. Shabanov, G. A. (1991). Razvitie pedagogicheskogo tvorchestva prepodavatelei voennouchebnykh zavedenii [Development of teachers' pedagogical creativity of military educational institutions]. (Extended abstract of candidate's thesis). Moscow [in Russian].

8. Yasinets, P. S. (2008). Yakist osvity u VNZ [Education quality in higher education institutions]. Kyiv: Libra [in Ukrainian].

Mkrtichian O. A., orcid.org/0000-0003-4962-3631

\section{CRITERIA, INDICATORS AND READINESS LEVELS OF EDUCATORS}

\section{FOR THE DEVELOPMENT OF MUSICAL ABILITIES IN CHILDREN AGED 4-7 YEARS}

The article is devoted to the topical issue of preparation of the educators in preschool institutions for the development of musical abilities in children aged 4-7 years. A systematic approach to the research problem indicates that criteria, indicators, levels of readiness of educators for the development of musical abilities of children 4-7 years can not be considered as isolated, selfsufficient elements of training. The author proves that the transition from one level of the educator's formed readiness to another is characterized by creation of a new system of relations between the elements. The system of component criteria and their qualitative indicators of readiness formation 
in educators of preschool institutions, for development of musical abilities of children of 4-7 years, according to structure of this phenomenon, reflecting author's model representations about its maintenance and features, was developed.

Based on the definition of the essence of "readiness of educators of preschool institutions for the development of musical abilities in children 4-7 years old" concept, its components were characterized. The value-motivational component is assessed using the motivational-axiological criterion, cognitive component - by operational-semantic criterion, activity component - by activity-reflective criterion. The defined criteria are characterized by indicators: motivational-axiological criterion - by value attitude to the future pedagogical activity, interest in mastering the forms, methods and techniques of the development of musical abilities in children aged 4-7 years; the need to succeed in professional activities; operational and semantic criterion - by consistency, efficiency; activity-reflection criterion by the formation of skills and abilities to develop musical abilities in children aged 4-7 years; educator's self-assessment of the formed readiness for this type of activity.

The author differentiated the readiness levels of educators for the development of musical abilities in children aged 4-7 years, on the basis of the traditional three-level gradation (high, medium, low). Based on the analysis, the author revealed the content essence of the readiness of educators of preschool institutions for the development of musical abilities in children aged 4-7 years, the components of readiness were determined, and the criteria, indicators and levels of formation of the denoted readiness were substantiated.

Key words: training, readiness, educator, development of musical abilities, children aged 4-7 years, criterion, indicator, level of formation.

Дата надходження статті: 17.10.2020 p. Рецензент: доктор педагогічних наук, професор Жерновникова О.А.

УДК [378.091.2.013:341](44)

DOI https://doi.org/10.37915/pa.vi46.127

Писаревська О. В., orcid.org/0000-0001-5166-1464

\section{МОДЕЯЬ ФОРМУВАННЯ СТРАТЕГІЧНОЇ КОМПЕТЕНТНОСТІ МАЙБУТНІХ ЮРИСТІВ-МІЖНАРОДНИКІВ В УНІВЕРСИТЕТАХ ФРАНЦІЇ}

У статті проаналізовано актуальні підходи до моделювання як методу дослідження педагогічних процесів і явищ, що дозволяе виявити їх основні компоненти та описати взаємозв'язок і умови функціонування. Розглянуто поняття стратегічної компетентності майбутнього ториста-міжнародника, яку в межах нашого дослідження розуміємо як складну, диналічну, інтегративну систему особистісних якостей та професійно-значущих знань, умінь $і$ навичок, спрямованих на адекватний $і$ ефективний вибір стратегій $i$ тактик у професійній діяльності, щзо набувають студенти під час професійного навчання. У статті представлено результати дослідження процесу формування стратегічної компетентності правників на прикладі навчання юристів-міжнародників в університетах Франції у вигляді авторської моделі формування зазначеної компетентності. Результати аналізу науковопедагогічних джерел та нормативних документів дозволили визначити п'ять основних взаємопов'язаних блоків розробленої моделі: цзільовий - містить соціальне замовлення суспільства, мету та завдання формування стратегічної компетентності; методологічний включае ї̈ компоненти (змістовий, професійно-когнітивний, діяльнісно-оперативний, комунікативно-інформаційний та особистісно-мотиваційний) та основні принциии і підходи

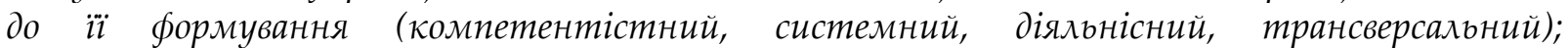

“(C) Писаревська О.В.

U3 193 